the introduction of a strain of wheat, of easy cultivation, which will combine high yield with quality and give a satisfactory straw. Usually in India, as elsewhere, the consistency of a wheat varies greatly, according to the conditions under which it is grown. Although weak wheats can be improved to some extent in milling and baking qualities by cultivation, they have not been made to behave like strong wheats. Owing to the shortness of the growth-period and the liability of the water-supply to deficiency, moderate-yielding wheats are on the average the most profitable to the grower. The Pusa experiments, which have been in progress since 1907, show that the strong wheats with good milling properties retain these properties both under canal irrigation and on the black. soils, and that high yield and high quality can be combined in the same wheat.

Such adverse factors as waterlogging and late cultivation affect both the yield and quality of the wheat, and the ryot requires training to the fact that rice conditions of drainage will not do for wheat cultivation. As elsewhere, the greatest financial return for the labour is obtained by growing to perfection a wheat which combines yield with quality.

We believe that the type of wheat preferred by the natives for their home consumption is altogether different from the strong wheat so desired for the export market : the authors ignore this point, but it would appear undesirable to sacrifice the home to the export market for the sake of such an elusive quality as strength.

E. F. A.

\section{PROF. JOHN MILNE, F.R.S.}

TO few men is it given to follow the growth of a new science from its infancy to maturity, and to still fewer to be prime movers in bringing about such a development. Nevertheless this is the claim we can confidently make for Dr. John Milne. He found seismology in its embryo stage, as left by the pioneer Robert Mallet-with its instruments of the most unsatisfactory type, its observational methods of the crudest description, and its inferences far from conclusive-but he lived to see well-equipped seismographical observatories scattered all over the globe, seismological societies established in every civilised State, and the science of seismology universally recognised as an important and highly suggestive branch of geophysics. And it was undoubtedly to Milne's genius and energy that the impulse leading to these results has been largely due. Yet he had not reached the age of sixty-three when he died on July $3 \mathrm{I}$, and his earthquake studies were comprised within a period of thirty-five years!

The two halves of this period of incessant activity had each its particular outlook-the first mainly confined to earthquake-shaken Japan; the second extending to the whole globe. At the early age of twenty-five, Milne, a student from the NO. 2284 , VOL. 9I]
Royal School of Mines, with a short experience in Newfoundland, Labrador, and Arabia, was appointed Professor of Geology and Mining in the University of Tokyo. Active as the young professor was in his teaching work, writing textbooks on crystallography and mining, and conducting expeditions to study the volcanic and other phenomena of Japan and neighbouring lands, it was, nevertheless, outside his official duties that he began to find the fullest scope for his superabundant energies.

It was the frequent earthshakings of his adopted country that supplied food to Milne's inquiring and speculative mind. Before he was thirty he had founded the Seismological Society of Japan, and a seismological journal; but for the first ten years at least Milne might have truthfully asserted, "I am the Seismological Society, and I write, as well as edit, the journal." He established observing stations all over Japan, eventually reaching nearly Iooo in number, each of which was supplied with a register in the form of a cheque-book, and the "cheques," filled up with answers to questions in Japanese and English, when posted to Milne, supplied him with the means of drawing "isoseismal" lines on his maps for each shock. But this laborious task, with earthquakes of almost daily occurrence, was only a small part of his work. He invented and improved various forms of recording instruments, investigated the laws of transmission of vibrations through the earth's crust by "artificial earthquakes," studied the principles on which buildings that should be "earthquake-proof" may be constructed, registered the meteorological conditions under which earthquakes occur, and perseveringly followed innumerable clues in diverse directions that continually suggested themselves to his ever-open mind.

Not the least important part of his work was the training a band of native observers, who are ably continuing and extending Milne's investigations in Japan. More than one hundred memoirs, filling more than two-thirds of the nineteen volumes of the Transactions and Journal of the Seismological Society of Japan, constitute the best evidence of Milne's devotion to the science during his seventeen years of residence in the country.

But Milne's retirement from the Japanese professorship at the age of forty-five furnished the opportunity for entering on a wider sphere of labour-one to which he was able to devote the whole of his time and effort. Just before starting for England, however, a most disastrous fire destroyed his accumulated books and instruments - the most serious loss being that of the stock of precious volumes of the Transactions and Journal of his society.

Undismayed by this misfortune, Milne, within three weeks of his arrival at home, had built a brick pillar at Shide, in the Isle of Wight, and set up on it his seismographs. The site of this now famous observing station had been selected from 
its proximity to a line of great earth-movements during a late geological period. Established at this centre, he entered upon the task of enlisting the aid of Government departments, public institutions, and private individuals to his great work. Before he died he had the satisfaction of having forty observing stations, all furnished with his own type of seismometer, in constant correspondence with him. The careful tabulation and discussion of the records from these observatories had occupied him during the last seventeen years, and the results have been given to the world in a series of circulars and reports by the British Association, the society which, so far as its means have allowed, has constantly subsidised and published Milne's work; in later years the Royal Society has extended its powerful support to him.

To readers of NATURE it is not necessary to enlarge on the results of Milne's labours since his return to England. His important work in tracing the cause of the fracture of submarine cables; his determination of the sites of distant earthquakes from seismographic records; his proof of the distinction between vibrations that travel through the earth, and those going round it; and many other suggestive contributions, are familiar to everyone.

No more striking proof of Milne's remarkable activity can be afforded than the fact that while the British Association has, since the year $184 \mathrm{r}$, published fifty-three reports on seismology, in which 562 communications are embodied, no fewer than 463 of these are from the pen of Milne! And all are in addition to his books and numerous articles in scientific and other journals.

The eighteenth (alas! it is the last!) of the luminous reports prepared since his return to England is now in the press, and will be presented at the forthcoming meeting of the British Association. It fittingly concludes with a touching and generous obituary notice of his Japanese assistant, Shinobu Hirota (the faithful "Snow"), who returned home to die last April. But, indeed, Milne's was an ever-generous soul. Students of seismology from all lands visited Shide, and were always warmly welcomed by Milne, often partaking of his hospitality. Not only these, but idle tourists, journalists in search of "copy," teachers with their pupils, and even children, were ungrudgingly received. In spite of his exacting labours, he seemed ever ready to show his instruments and talk about his work with the most casual visitor.

Some, perhaps, may suggest that Milne was wanting in sympathy with the work of co-ordinating the results of other organisations than his own; and it may be admitted that his Pegasus did not run well in harness. But it must be remembered how, from the first, he had been accustomed to bear all the weight and responsibility of great enterprises on his own broad shoulders. John Milne's death is indeed a great calamity for science-how great will only be realised when the attempt is made to supply his place.

NO. 2284, VOL, 91$]$

\section{NOTES.}

THE Baly medal has been awarded by the Royal College of Physicians to Dr. J. S. Haldane, F.R.S., reader in physiology at the University of Oxford, in recognition of his distinguished contributions to physiological science.

Prof. W. C. McInTosh, F.R.S., professor of natural history in the University of St. Andrews, and director of the Gatty Marine Laboratory, has been elected president of the Ray Society in succession to the late Lord Avebury.

THE death is announced of Mr. T. H. Russell, of Birmingham, who was a fellow of the Linnean Society and the author of a work on mosses and liverworts.

A PARAGRAPH in The Times of August 2 states that there are 106 clocks attached to premises in the City of London, and observable from the public way. Of these, forty-two are synchronised from Greenwich Observatory. There are, in addition, twenty-nine church clocks in the City (including St. Paul's Cathedral), none of which are synchronised or even unanimous in their irregularity.

IN a letter published in The Scotsman of July 24, Dr. John G. Havelock, of Montrose, describes some observations which have led him to conclude that common varieties of the single petunia are true insectivorous plants. Mr. Alex. Johnstone, of the same town, has sent us an account of observations of his own which suggest the same conclusion. Sir Herbert Maxwell, in The Scotsman of July 28, thinks Rhododendron barbabum also deserves attention as probably an insectivorous plant. Only a careful experiment can determine the accuracy of the suggestion that Petunia is insectivorous, and it may be hoped the point will receive the attention of plant physiologists.

THE exhibited collection of Mesozoic crocodiles in the Geological Department of the British Museum (Natural History) has just been rearranged to incorporate some important recent acquisitions. A new specimen of Mystriosaurus from the Upper Lias of Würtemberg, prepared by Mr. B. Hauff, is one of the finest known examples, with almost complete limbs. The stomach-contents are seen, mingled with swallowed pebbles. A specimen of Geosaurus, from the Lithographic Stone of Bavaria, shows for the first time the triangular tail-fin by which this essentially marine crocodile propelled itself. The unique example of the Wealden river-crocodile Goniopholis, discovered a few years ago by Mr. R. W. Hooley in the cliff near Atherfield, Isle of Wight, and described by him in the Geological Society's Journal, has also been mounted and exhibited.

THE sixtieth birthday of Prof. W. Ridgway was fittingly commemorated a few days ago by a dinner at Caius College, Cambridge, attended by scholars and men of science from all parts of the kingdom. Few archæologists of the present day have done more, by original work, stimulating instruction, and the application of anthropological methods in the solution of historical problems, to advance English scholarship. His treatises "The Origin of Currency 